\title{
QASR EL-FARAFRA: ITS SPATIAL ORGANIZATION, INFRASTRUCTURE AND SOCIAL SERVICES AS SEEN IN 1993
}

\author{
THE SETTLEMENT LAYOUT
}

Qasr el-Farafra, the main and original centre of the Farafra oasis, was settled on the top of gebel - a great sand dune of $0.4 \mathrm{sq} . \mathrm{km}$ in area culminating about $40 \mathrm{~m}$ above the surrounding desert. The shape of the gebel resembles a huge "bean" (see Fig. 1) with two highest points slightly raised above the contour line of the dune. In medieval times the castle was erected on the northern top (its ruins can be seen today), while the cemetery (ar mizar) was established on the southern top. Between the two tops there is a wide flattened area, where - as in the old times - the market square is situated. Today, there are also some institutions denoting new times, i.e. the building of public administration, a small hospital and the school.

Original buildings were concentrated near the castle. The old spatial layout of the streets, as well as the most interesting examples of traditional architecture can be observed there. The functional layout of historic Qasr el-Farafra shows that the original settlement was isolated due to the elevation and concentration around the castle. The market square was situated outside the settlement underlying the northern top of the gebel. The cemetery was established near the utmost edge of the great dune, which is eroded and waterless. And the gardens were planted on the western slope of the great dune, due to the spring existing here (the so-called "Roman well" on the map).

The growth of population and recent completion of a modern road influenced the change in town planning. As a result, the new houses were built up outside the main top on the eastern slope of the dune, near the road. Also the shops, restaurants and other services have recently been located in this area. The newest houses, especially those which were built up on the southern outskirts of Qasr el-Farafra, evidently differ from the old traditional architecture. Although they still remain large family units, they are less separated and have lower walls isolating them from the strangers. They are made of different material containing more wood and clay bricks 


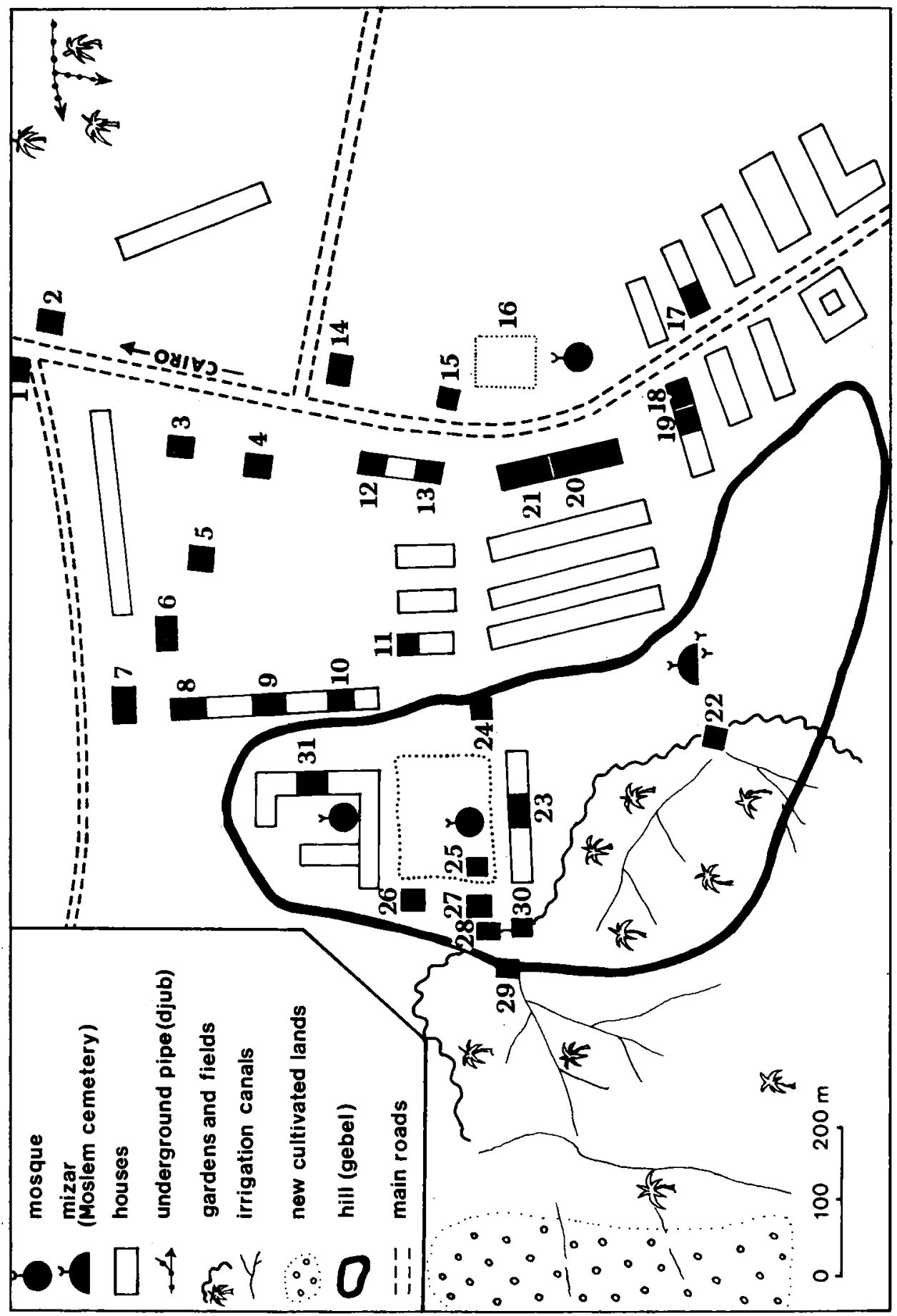


instead of traditional bricks made of dried mud mixed with chaff. In this part of Qasr el-Farafra the streets go directly from the main road, while in the older parts of the town they deviate from the lateral secondary roads. This change of spatial network seems to be another sign of decreasing family isolation.

The last observation illustrates, in our opinion, the most significant spatial transformation of the settlement observed since Bliss carried out his research in 1981. The map of Qasr el-Farafra drawn by Bliss in 1981 suggests, however, that the tendency towards this transformation might start already in 1965-71 (on Bliss's map, the eastern part of the settlement underlying the oldest sector and mizar).

\section{COMMUNICATION}

The first modern road in Farafra led from Dakhla. It was only the toughened road for heavy machines brought here for drilling new, deep wells, since the main spring of Ain el-Bilad nearly dried out in the $1950 \mathrm{~s}$ and the discharge of other springs dramatically decreased (Fakhry 1974, p.176). However, the turning point was the completion of a regular road from the northern side in the early 1980s, which connected Farafra with Cairo via the Bahariya oasis. This permitted a regular communication with the capital and other oases. It markedly shortened the time of travel to Farafra. However, the old Farafran people still traditionally define the distance between Farafra and Dakhla as 7-8 days of camel's caravan voyage by a new road or 4 days' travelling via the old route.

The completion of the new road gave rise to the development of motor transport. Traditional transport, like camels and donkeys, was gradually ousted by cars, jeeps, lorries, motor-cycles and tractors. Today, about 50 men at Qasr el-Farafra possess driving licenses.

As a result, the number of camels, that used to be the only means of long-distance transport, dramatically decreased during the last 10 years: from more than 100 to a dozen or so. Now they are mostly a tourist attraction and are used by tourists for short trips to the desert or are bred for the wool. The donkeys are still much used for transportation; one can see them carrying people or goods or drawing traditional two-wheeled carts.

The development of motor transport may be evidenced by the number of tractors. They are being used for fieldwork or for transport. The first tractor came to Farafra in the early 1970 s. At present, there are nearly 100 trac-

Fig. 1. Qasr el-Farafra - simplified plan: 1 - agricultural cooperative, 2 - petrol station, 3 restaurant, 4 - resthouse, 5 - post office, 6 - secondary school, 7 - Badr's Museum, 8 shop, 9 - shop, 10 - car electrician, 11 - shop, 12 - meteorological station, 13 - police station, 14 - rural bank, 15 - restaurant, 16 - football ground place, 17 - vulcanization workshop, 18 - restaurant, 19 - bakery, 20 - restaurant, 21 - resthouse, 22 - old spring ("Roman well"), 23 - shop, 24 - barber, 25 - governor's office, 26 - hospital, 27 - primary school, 28 - electrical mill, 29 - New deep spring, 30 - generator, 31 - ruins of the castle 
tors including those used in the new villages. Many families cannot afford to buy a tractor since the new one costs about 30 thousand Egyptian pounds, while the second-hand tractor costs 2 thousand pounds. As a result, the common purchase by $2-4$ families is often observed here. The poorest peasants may rent tractors and other machines from the local co-operative. The charges for the services rendered by the co-operative are relatively low, e.g. 12 pounds per one hour of the work of a small tractor. The tractor may also be bought on credit from the rural bank. In the beginning of 1993 the interest rate was $20 \%$ yearly.

Most of heavy agricultural stuff, such as combine harvesters or thrashers were brought to Farafra due to the international assistance under the New Valley Project. They do not belong to individuals but are administered by co-operatives or local agricultural authorities. Other machines, e.g. sowing-machines, harvesters, mowers etc. are already common at Qasr el- Farafra. They are tax-free and they may be purchased from the rural bank.

There is one petrol station at Qasr el-Farafra. It is situated near the main road on the northern outskirts and is open 24 hours. It also offers spare parts, batteries and propane-gas. The prices for fuel are officially fixed.

\section{ELECTRIFICATION}

The first electricity unit was installed at Farafra in 1981. It brought about mechanization of some household work. For example, the people of Qasr el-Farafra received from the international aid programme an electrical grinding-mill which replaced a traditional hand-mill. However, the oil made of olives is still manufactured in the traditional way (Bliss 1983, pp. 162-167). A big number of olive trees leads to the surplus of fruits that are difficult to sell. To solve this problem, a small oil plant is planned to be established at Qasr el-Farafra.

Due to electrification economic activities may be continued also after the sunset. Some small enterprises work only while the power unit is active. It operates since the evening praying called (by means of loudspeakers) by the muezzin and is switched off at $1.00 \mathrm{a} . \mathrm{m}$. In the summer time, it operates also during the day for one hour or so to keep the refrigerators' cooling. So far, monthly charges for electricity are fixed and amount to 10 Egyptian pounds per household. Also small enterprises pay a fixed fee for electricity. For example, the manager of the grain-mill pays 20 pounds a month. The charges are sufficient to cover only $50 \%$ of the cost of fuel used by Diesel, let alone the costs of maintenance.

According to the opinion of local authorities, the power plant could work 24 hours should the inhabitants accept higher fees. But in fact, they do not see any reason for using the electricity during the day. Even if they make 
use of refrigerators, they also know the other methods of food storing, and during the winter the refrigerators are not used at all. Local authorities are planning to establish another power station to provide electricity to the settlements outside Qasr el-Farafra.

\section{COMMERCE AND SERVICES}

Farafra's community was always self-sufficient in food, but some clothes and articles of everyday use were purchased in other oases or from the merchants' caravans (Fakhry 1974, pp.169-170). At present, there are 15 shops at Qasr el-Farafra including some service enterprises that also sell food and other commodities. There is also a small shop in the market square (an openair shop) that is working 24 hours. The shops sell food, clothes, cosmetics and detergents, as well as school articles for children. Only two of them are specialized in single goods, like chicken (brought from the other oases). In February 1993, a new electromechanical shop was opened.

There is also a barber's and a tailor's workshop. The latter makes only men's trousers. However, there are hardly any traditional commodities offered to tourists. They may buy only local wool products, such as jumpers, shawls, gloves or socks, as well as camel saddles and kilims. Kilims are locally manufactured by one producer only. As compared to kilims from the other regions of Egypt, e.g. Sinai, their designs are very simple with predominant rouge and beige colours.

\section{SOCIAL SERVICES}

\section{MEDICAL SERVICE}

The first hospital was built in the Farafra oasis 25 years ago. Since 1991, a new one has been in operation with 30 beds, 2 medical vans and a drugstore. It employs 2 doctors, 3 female nurses and 1 male nurse. Doctors are coming from the outside and are engaged for 6 months with a possibility of prolonging. There are four Farafrans who graduated from high medical schools, but all of them are employed outside the oasis.

The most frequent cases treated in the hospital are sunstroke and alimentary canal diseases. The most dangerous cases are treated in the hospitals of the Bahariya and Dakhla oases.

\section{EDUCATION}

The first school or rather centre of learning mostly teaching religious doctrines, called zawiyah, was founded around 1850 (Fakhry 1974, p. 168). In 1938, the so-called old primary school was established. Until 1950, it was 
the only elementary school with one teacher. At present, there are two schools: primary and, a more recent, preparatory school. The latter was founded thanks to the American assistance and to some extent it also serves as a secondary school with a limited number of pupils.

The present staff consists of 25 teachers (including 8 women) with one director and 3 technicians in the primary school, while in the secondary school there are 36 teachers ( 4 women). Some of them are coming from the other oases.

In 1993, the number of pupils was 358 in primary school and 260 in preparatory school. There are also 24 pupils in secondary school. At present, the possibilities of higher education, particularly vocational training, in the Farafra oasis are insufficient so that the young people must attend the schools outside Farafra: in Asyut, Faiyum, Kharga or even Cairo.

The economic and administrative advance of the oasis requires educated and specialized personnel. At present, some 40 people, excluding school teachers and private entrepreneurs, have salaried jobs in the local administration, police, at the post-office and in the meteorological station. Due to the civic rights accorded to Qasr el-Farafra in January 1993, the number of administrative workers is likely to increase. 